\title{
ISLAMIC BANK SAFETY NET ISSUES: THE REGULATORY CHALLENGES FOR CROSS BORDER ISLAMIC BANKING TRANSACTIONS
}

\author{
Dr. Abul Bashar Bhuiyan \\ Associate Professor \\ Faculty of Business and Accountancy \\ University of Selangor, Shah Alam, Malaysia \\ E-mail: bashariuk@gmail.com \\ Dr. Abdul Ghafar Ismail \\ Professor of Islamic Financial Economics \\ Universiti Sains Islam Malaysia, Malaysia \\ E-mail: agibab62@gmail.com
}

\section{K. M. Anwarul Islam}

Associate Professor

Department of Business Administration

The Millennium University, Dhaka, Bangladesh

PhD Candidate

University of Selangor, Malaysia

E-mail: ai419bankingdu@ gmail.com

\section{Dr. Abd Halim Mohd Noor \\ Professor of Economics}

Universiti Technology Mara (UiTM)Malaysia, Melaka, Malaysia

E-mail: drabdhalim@bdrmelaka.uitm.edu.my

\section{Dr. Mohammad Solaiman}

Associate Professor

Department of Marketing

Comilla University

Cumilla. Bangladesh

E-mail: solaimanmktgcou@yahoo.com

\section{Dr. Mohammad Abdur Rahman \\ Assistant Professor}

School of Business Administration

Faculty of Business and Entrepreneurship

Daffodil International University, Dhaka, Bangladesh

E-mail: rahman@diu.edu.bd 


\begin{abstract}
This paper aims to identify major regulatory challenges in the safety net for providing insurances to the depositors in the cross-border transaction over the world.The study found that Islamic banking is facing major challenges to issue appropriate rules and regulations for providing the right safety against the deposit of customers with a conventional counterpart base on the Islamic shariah principles. Especially in the area of "chartering or licensing function, prudential regulation and supervision, deposits in the central bank, intervention and resolution mechanisms and capital adequacy standard" for safety net issues of Islamic Bank. The study recommended that the policymakers need to pay heed in a deliberate and intentional way to solve the above regulatory issues to face the existing challenges for the smooth operation and bright prospect of the Islamic Banking sector in the future.
\end{abstract}

Keywords:Safety Net, Islamic Banking, Regulations, Cross Border Activities.

JELClassification Codes: G21, G24, L26, P51.

\title{
INTRODUCTION
}

The Islamic Banking is facing enormous critical challenges in the issues of safety net for providing insurances to the depositors in the cross-border transaction over the world. As the part of safety net issues, the Islamic deposit insurance is a very new concept and there are some operational issues and challenges that need to be prudently researched and addressed. Much still need to be done to build-up a efficacious Shariah deposit insurance standards. The IFSB (Islamic Financial Services Board) is working to set up Islamic banking standards. The landscape of Islamic Banking evolved dramatically as many Muslim countries started to introduce the system. Islamic banking now exists in over 75 countries around the world, with over 300 Islamic banking institutions (Abdul-Rahman, 1999; Naghipour, Rasht, \& Pourmohammad, 2012). With the increasing demand of Islamic mode of financing from the cross countries' customers, the Islamic Bank is offering cross border opportunity of transaction in the global market. But the services of Islamic Banking are not available in the whole part's global arena where two or more Islamic Bank can do agreement to provide facilities to their customer based on Islamic shariah. In such circumstances it is very difficult for Islamic Bank to operate and find an alternative way for the cross border transaction (Sundararajan \& Errico, 2002; Van Greuning, Iqbal, \& mondiale, 2008). On the other hand, there are many more conventional banks who are offering the Islamic banking products to their Muslim customers within the national and international perspective. For providing Islamic Banking services to their clients, they open an Islamic banking window or Islamic banking section (Mohammad Kabir Hassan \& Mehmet F. Dicle, 2005).

The Islamic banking is offering depositors on the basis of sharing of profit and loss bearing on original capital, due to the probability of the risk of loss of deposit, bank should be provided proper insurances with sufficient capital in the central bank or anywhere else to meet up the safety net demand of clients. In addition to those risks commonly faced by conventional banks, Islamic banks face other unique risks as a result of the different characteristics of their asset and liability structure. The aim of this paper is to depict an in- depth discussion on capital adequacy standard and deposit insuranceconsidering the Islamic Banking system across the globe among the cross-border activities. 


\section{SAFETY NET ISSUES}

The safety net is the way of providing security to protect risk against the probability of bearing loss of deposit capital. Because of the Islamic bank are offering depositors on the basis of sharing of profit and loss bearing on original capital, due to probability of the risk of loss of deposit, bank should be provided proper insurances with sufficient capital in the central bank or anywhere else to meet up safety net demand of clients (Abdul-Rahman, 1999; Bashir, 1999; Naghipour et al., 2012). In addition to those risks commonly faced by conventional banks, Islamic banks face other unique risks as a result of the different characteristics of their asset and liability structure. Therefore, the safety net arrangements are intended to maintain the stability of the Islamic Banking system by providing certain insurances to the depositor in the way of safety of their capital. The components of safety nets are as follows.

\section{Deposit Insurance}

The deposit insurance is a process of providing explicit protection in the form of a promise to pay depositors of banks if any failure of bank for occurring loses. This system increases the confidence in the Islamic banking, thereby reducing potential contagion to healthy banks. Globally, deposit protection has become an integral part of the financial safety net. Furthermore, the deposit insurers that are effective are those that are structured and well placed to deal with a bank failure or a wave of bank failures. The main objective of establishing a deposit insurance system is to protect the depositors money and prevent their money from facing financial difficulty in the event of a bank failure (Z. Iqbal \& Mirakhor, 1999; Lewis \& Algaoud, 2001).

On the other hand, the Islamic deposit insurance enhances the confidence amongst members of the public in the safety of their deposits contributes and promotes to financial stability in the cross-border transaction of Islamic banking. This is even more important and relevant when the contribution of the Islamic banking industry to a country's economy is significant and has integrated well with the banking system. Furthermore, it also makes the competitiveness of the Islamic deposits and the banking system. Without the protection, Islamic deposits may lose their competitiveness against the conventional deposits which enjoy such protection (El-Hawary, Grais, \& Iqbal, 2004; Muljawan, Dar, \& Hall, 2004). As a result, there is a possibility that the depositor would withdraw their funds in Islamic banks and placed it with conventional banks and this would create liquidity shortages to Islamic banks and may dampen the development of the Islamic banking industry.

\section{Regulatory Challenges for Deposit Insurers}

A well-structured and effective deposit insurer ensure to build public confidence through well governed and well managed activities by the both parties. Because of trust and prudence are cornerstones of public confidence. It must be transparent in their operation to the depositors for increasing awareness of deposit insurance benefits and limitations to help mitigate bank runs during bad times. The Islamic Banking is the amazing sectors in the world economy with facing many folds of challenges with counter parts. Because they have to follow the shariah guidelines to offer any types new investments (M.K. Hassan \& M.F. Dicle, 2005; I.F.S.B, 2005; Van Greuning et al., 2008).

\section{- Lack of guidelines and regulatory documents}

As the deposit insurances increase the confidence in the Islamic banking, thereby reducing potential contagion to healthy banks. Globally, deposit protection has become an integral part of 
the financial safety net. But there is the absence of guidelines and regulatory documents for Islamic deposit insurance, which are approved by shariah laws. As the new but amazing field economy Islamic Bank sharia council should prepare appropriate rules and regulations to protect their depositors by minimizing risk of any further loss in the crises times (Bashir, 1999; Weigand \& Grosh, 2008).

\section{- Issues of Contacts}

As the demand of growing customer Islamic banks is introducing rapidly more innovative and dynamic products were being offered to the public, there were options utilize either one contract or multiple contracts within a product. In this respect, we need to be able to assess the insurability of these products as well as their priority of payment. This is the another challenges are facing by Islamic Bank to ensure risk free investment in the different mode of banking(Bashir, 1999; Weigand \& Grosh, 2008).

\section{- Issues of Disposal Assets}

It is more important to ensure the effectiveness of the Islamic deposit insurance system. Especially in the issues of the disposal of assets of an insolvent Islamic bank. Given the unique structure of the operations of Islamic banks, the disposal of assets should take into account the existence of general and specific PSIA that may require separate reimbursement approaches (Muljawan et al., 2004; Sundararajan \& Errico, 2002; Van Greuning et al., 2008).

\section{- The lack of skilled human capital}

The lack of skilled human capital is not a new issue within the Islamic financial system. Especially in the Islamic financial industry, Islamic deposit insurance is very new but very important operational issues and challenges are required to solve that need to be researched and well addressed. Much still need to be done to build-up Shariah deposit insurance standards. In such circumstances, to build up skilled human capital for the Islamic bank in the specific issues, are one of main challenges (Muljawan et al., 2004; Sundararajan \& Errico, 2002; Van Greuning et al., 2008).

\section{Capital Adequacy Standard}

The capital adequacy is another important instrument for providing security of depositors to protect their probable losses. The recently issued Islamic Financial Services Board (IFSB) Capital Adequacy Standard recommends that supervisors should assess the extent of risks born by the islamic banking operations. The capital would be based on management decisions on the payout to IAH, and should reflect these assessments in the computation of capital adequacy. The IFSB has been seted up standard of supervisory discretion formula which is known as capital adequacy ratio (CAR) specifies that a fraction "alpha" of the assets funded by PSIA may be included in the denominator of the CAR, where the permissible value for "alpha" is subject to supervisory discretion. The supervisory assessment of how an IIFS manages the risk-return profile of PSIA would determine "alpha", with "alpha near zero" reflecting a pure investmentlike product, and "alpha close to one" capturing a pure deposit-like product (Muljawan et al., 2004).

The capital adequacy standard are assuring to the depositors by keeping sufficient assets in a fund conducted by an insurer to provide adequate capital for the conduct of the fund in accordance with this Act and in the interests of the policy holders of the fund. The Capital 
Adequacy Reserve to be calculated under this standard for each fund conducted by an insurer is an assessment of the financial strength of the fund on the basis of an ongoing operation. The Capital Adequacy Reserve must be sufficient for the fund to be expected to remain solvent for at least the next three years after the valuation date, on the basis of assuming future experience during that period in accordance with the best estimate experience underlying the current business plans of the insurer.

\section{Principles for Required Capital Adequacy}

The capital adequacy requirements are based on the definition of (eligible) regulatory capital and risk-weighted assets (RWA) of the Standard for shariah compliant instruments. The minimum capital adequacy requirements for IIFS shall be a CAR of not lower than $8 \%$ for total capital. Tier 2 capital is limited to 100\% of Tier 1 capital (I.F.S.B, 2005; Muljawan et al., 2004).

\section{- Credit Risk}

The credit risk exposures in Islamic financing arise in connection with accounts receivable in Murābahah contracts, counterparty risk in Salam contracts, accounts receivable and counterparty risk in Istisnā ' contracts and lease payments receivable in Ijārah contracts, and sukuk held to maturity in the banking book. In the standard, credit risk is measured according to the Standardised Approach of Basel II, as will be discussed below, except for certain exposures arising from investments by means of Mushārakah or Mud̄arabah contracts in assets in the banking book (I.F.S.B, 2005; Muljawan et al., 2004).

\section{$\checkmark$ Individual Claims based on External Credit Assessments}

To assess the external credit assessments of individual claims, the supervisory authorities have the discretion to reduce the RW for exposures to the sovereigns and central banks that are denominated and funded in domestic currency. It is inclusive of official entities that will receive a $0 \% \mathrm{RW}$ as determined by supervisory authorities. It may be risk-weighted as sovereigns if they have the power of raising revenue and a specific institutional arrangement to reduce their default risk especially for regional government and local authorities. An administrative body owned by the government or a local authority may be treated in the same manner as IIFS even though it has sovereign immunity but has no power of raising revenue or a specific institutional arrangement. There are certain MDBs are eligible for a $0 \% \mathrm{RW}$ as determined by the supervisory authorities. The RW are one category less favourable than that assigned to claims on the sovereigns subject to a floor of $20 \%$ when the exposure is denominated and funded in domestic currency. An unrated corporate shall not be given a preferential RW compared to its sovereign. Supervisory authorities have discretion to require a RW higher than $100 \%$ or to allow all corporates to be risk-weighted at 100\% (I.F.S.B, 2005; Muljawan et al., 2004).

\section{$\checkmark$ Off-balance Sheet Exposures}

The off-balance-sheet items under the standardised approach will be converted into credit exposure equivalents through the use of credit conversion factors (CCF). There are commitments with an original maturity up to one year and commitments with an original maturity over one year will receive a CCF of $20 \%$ and $50 \%$, respectively. However, any commitments that are unconditionally cancellable at any time by the IIFS without prior notice, or that effectively provide for automatic cancellation due to deterioration in a borrower's creditworthiness, will receive a $0 \% \mathrm{CCF}$. An import or export financing, which is based on Muräbahah where the 
underlying goods/shipment are collateralised and insured, shall attract a $20 \%$ credit conversion factor to the IIFS that issues or confirms the letter of credit (I.F.S.B, 2005; Muljawan et al., 2004).

\section{$\checkmark$ Exposures in Investments Made Under Profit Sharing Modes}

Most of the Islamic Bank investments made under profit-sharing and loss-bearing mode (Muḍārabah) and profit and loss sharing mode (Mushärakah) that are made not for trading or liquidity purposes but for the purpose of earning investment returns from medium to long-term financing. Such investments are not held with the intent of trading or short-term resale benefiting from the actual or expected price movements; it is also not marked-to-market on a daily basis; even not actively monitored with reference to market sources; and exposed to credit risk in the form of capital impairment risk (I.F.S.B, 2005; Muljawan et al., 2004).

\section{- Market Risk}

The market risk is defined as the risk of losses in on- and off-balance sheet positions arising from movements in market prices. The risks in Islamic Banking sectors that are subject to the market risk capital requirement are (I.F.S.B, 2005; Muljawan et al., 2004):

$\checkmark$ The equity position risk in the trading bookand market risk on trading positions in Sukūk

$\checkmark$ The foreign exchange risk; and

$\checkmark$ The commodities and inventory risk.

\section{- Operational Risk}

The operational risk is a types of risk of losses resulting from inadequate or failed internal processes, people and systems or from external events, which includes but is not limited to, legal risk and Shari ${ }^{\prime}$ h compliance risk. The operational risk in Islamic bank may be based on either the Basic Indicator Approach or the Standardised Approach as set out in Basel II. Under the Basic Indicator Approach, a fixed percentage of 15\% of annual average gross income, averaged over the previous three years, is set aside. Under the Standardised Approach, this percentage varies according to the line of business (LOB) from $12 \%$ to $18 \%$, being $18 \%$ for corporate finance, trading and sales, and payment and settlement, to $15 \%$ for commercial banking and agency services, and 12\% for retail banking, asset management and retail brokerage. As the LOBs into which IIFS are organised are different from the above, it is proposed that, at the present stage, the Basic Indicator Approach be used by IIFS, which requires the setting aside of a fixed percentage of average annual gross income over the previous three years. Subject to the supervisory authority defining the applicable business lines, the supervisory authority may allow IIFS in its jurisdiction to apply the Standardised Approach in which the percentage $(12 \%, 15 \%$ or $18 \%$ ) of gross income is to be set aside according to the business lines (I.F.S.B, 2005; Muljawan et al., 2004).

\section{- Profit Sharing Investment Accounts}

The capital adequacy requirement for assets financed by Profit Sharing Investment Accounts (PSIA), a pool of investment funds placed with an Islamic Banking on the basis of Muḍarabah. Where investment accounts are managed under Wakälah contract, the relationship between Islamic Bank and the investors is a simple agency relationship with the Islamic Banking earning a flat fee rather than a share of profit. The Islamic Bank has full discretionary power in making investment decisions for unrestricted PSIA, but in the case of the restricted PSIA the placement 
of funds by Islamic Banking is subject to investment criteria specified by the Islamic Bank in the Mud̄a rabah contract or agreed between the investment account holders (IAH) and the Islamic Bank at the time of contracting (I.F.S.B, 2005; Muljawan et al., 2004).

\section{Chartering or Licensing Function}

In the conventional banking system Chartering or Licensing Function is one of financial safety structure is performed either by the ministry of finance, central bank and/or supervisory authority but certain deposit insurers also play that role, such as the Federal Deposit Insurance Corporation. Where the bank keep minimum set-up capital and character requirements on the underlying financial sector for ensuring that the new entries to the financial system have sufficiently capital to conduct sound business and financial operations to prevent imprudent, incompetent, or dishonest individuals from entering the system. It is applicable also Islamic Banking operation because most of the Islamic banking are running under conventional central bank over the world (El-Hawary et al., 2004; Sundararajan \& Errico, 2002).

\section{Prudential Regulation and Supervision}

The prudential regulation and supervision is alsofunctioning asa disclosure of capital adequacy requirements as well as restrictions on selected business activities. It reduces unwarranted or unmitigated risk taking while supervision is to monitor banks to ensure that they are complying with the regulations in order to maintain the safety and soundness of the banking system. This function is typically conducted by the central banks or by supervisory agencies. In the Islamic banking jurisdictions the deposit insurer conducts supervision, in one form or another, when their mandate includes risk assessment and monitoring and loss minimization objectives (Hegazy, 1995; Van Greuning et al., 2008).

\section{Deposits in the central Bank}

It is mandatory for all types of bank to keep a certain sum of their capital in the central bank as the safety of any defaults of banks. Due to this issue central bank promised to provide any necessary supports about liquidity to a solvent but illiquid bank, should a run against an institution occur. Should contagion occur, the lender of last resort can also provide liquidity to the banking system (Bashir, 2001).

\section{Intervention and resolution mechanisms}

In the most of the countries, central bank has supervised all types of banking activities and Islamic banks are also controlled by the same act of central bank as like as conventional bank (Mohammad Kabir Hassan \& Mehmet F. Dicle, 2005; JR.Barth, Caprio, \& Levine, 2000; Tahir \& Bakar, 2009). Some countries issue special Islamic banking Act to govern the operations of specific Islamic banks and their relationship with the central bank (Tahir \& Bakar, 2009). Thus, it is big difficulties for Islamic bank to adjust within same regulation with traditional interestbased convention banking. Even, to protect the public safety most of governments have created elaborate regulatory bodies for smooth operation of traditional banking over the cross countries separately. As a result, banking industry has become one of the most heavily regulated industries all over the world (Ahmad, Khan, \& Iqbal, 1998). Against this background, it is a timely requirement to establish a strong supervisory framework as the extension of a sharia council of Islamic banks. It would be provided right observation for all the regulatory obligations with central bank and Islamic Bank. Then it will help to find the safe and smooth way of opportunity 
for Islamic Banking activities from the existing rules and regulations of central bank respectively.

\section{REGULATORY CHALLENGES FOR CROSS BORDER ISLAMIC BANKING Financial Innovations}

Financial innovations are facing main challenge to cope up with the rasing demand from the customers through condition of sharing risk, lowering transaction costs, and reducing asymmetric information and agency costs(Zamir Iqbal, 2007). It is the process of making design, development, and implementation of innovative financial instruments and products as well as the formulation of creative solutions. Financial engineering may lead to a new consumer-type financial instrument, or a new security, or a new process or creative solution to corporate finance problems, such as the need to lower funding costs, manage risk better, or increase the return on investments (Ahmad et al., 1998; Zamir Iqbal, 2007). For the Islamic Banking perspectives, it is a prime challenge to introduce new Shariah-compatible products on the basis of understanding the risk-return characteristics of each building block of the system and offering new products with different risk-return profiles that meet the demand of investors, financial intermediaries, and entrepreneurs for liquidity and safety (Mohammad Kabir Hassan \& Mehmet F. Dicle, 2005; Zamir Iqbal, 2007; Tahir \& Bakar, 2009).

\section{Shariah Authority}

The shariah board who controll the whole banking system on the basis of islamic shariah and each bank have seperate shariah council to examines and evaluates each new product but there are mere coordinating with other banks within the boundary or cross boundary. Even each board addressed different particular school of thought. (Zamir Iqbal, 2007). There are diversity of opinion as to whether particular practices or products are Shariah compliant. This means that some products and services may be approved as being Shariah compliant by some Sharia scholars but not by others. On a global level, the approval of Islamic firms products and services may also depend on the jurisdiction they are to be offered in. This can add another layer of complication for regulators (Ainley, Mashayekhi, Hicks, Rahman, \& Ravalia, 2007). In the competive conventional market in the cross border arena, to expand the Islamic Banking services within the satisfation customer, it is an regulatory challange for Islamic Banking activities to solve this issues integrated and unique shariah decision can minimize time, effort, and confusion for innovation a new products. In such situations, Islamic scholars agreed to develop common Shariah standards organisations as similar as the Islamic Financial Services Board (IFSB) and the Accounting and Auditing Organisation for Islamic Financial Institutions (AAOIFI). Further more, for example, the IFSB has recently called for a dialogue within the industry to adapt current insurance regulations to meet the specifics of Islamic finance. Greater standardisation could reduce the potential for Shariah 'arbitrage' as well as making it easier for bankers and investors to understand the market (Ainley et al., 2007).

\section{Profit and Loss Sharing Financing}

Islamic mode of finances are operating on the basis of fixed charge on the capital investment and sharing profit from lending money and both of types provide financing through the purchase and sale of real commodities, but conventional financial transactions are based on lending and borrowing of money for a fixed charge (interest). In the context of cross border transaction of Islamic Banking are facing conflicts with conventional parts due to interest-based mentality 
rather profit and loss sharing financing. In some cases, Islamic Bank being used fixed-return mode of financing such as Murabahah and leasing that's are clearly distinguishable from the conventional mode of finance since the transaction with these mode are always on the basis of real commodities(Ahmad et al., 1998). For encouraging more and safe cross border activities, the Islamic Banks can be encouraged to provide more profit-sharing finance through reducing of operating cost by institutional appropriate arrangements as well as financial engineering consistent with the preferences of fund users along with shariah compliant.

\section{Supervisory Authority}

The most of the country central bank has supervised all types of banking activities and Islamic banks are also controlled by the same act of central bank as like as conventional bank (Mohammad Kabir Hassan \& Mehmet F. Dicle, 2005; JR.Barth et al., 2000; Tahir \& Bakar, 2009). Some countries issue special Islamic banking Act to govern the operations of specific Islamic banks and their relationship with the central bank (Tahir \& Bakar, 2009). Thus, it is big difficulties for Islamic bank to adjust within same regulation with traditional interest-based convention banking. Even, to protect the public safety most of governments have created elaborate regulatory bodies for smooth operation of traditional banking over the cross countries separately. As a result, banking industry has become one of the most heavily regulated industries all over the world(Ahmad et al., 1998). Against this background, it is timely requirement to establish strong supervisory framework as the extension of shariah council of Islamic banks. It would be provided right observation for all the regulatory obligations with central bank and Islamic Bank. Then it will help to find the safe and smooth way of opportunity for Islamic Banking activities from the existing rules and regulations of central bank respectively. In the cross countries issues where the central bank conducts open market operations, Islamic banks are unable to participate in these operations because of interest-based nature of the securities brought and sold. Thus, Islamic banks are constrained by the fact that financial assets that could be liquidated quickly are not available to them. This introduces some rigidity in the asset structure of Islamic bank's operations (Ahmad et al., 1998; Grais, 2008; Zamir Iqbal, 2007).

\section{Accounting Standards}

The proper accounting practices are an important issue for any financial institutions in the context of cross border activities. In general the conventional banks are practicing generally accepted international accounting standards that are used as reference and facilitate cross border assessments, and accordingly financial flows and investments (Ilias, 2010). In order to introduce standardization in the accounting practices of Islamic financial institutions, some Islamic banks, under the guidance of the Islamic Development Bank, have established an organization called Accounting and Auditing Organization for Islamic Financial Institutions (AAOIFI). The organization are functioning based in Bahrain, is composed of a supervisory committee and a Financial Accounting Standards Board responsible for preparing, issuing and amending the accounting standards of those Islamic banks and financial institutions that have agreed to apply the standards set up by the Board. The AAOIFI is a voluntary organization and has no binding powers to implements its standards but just to observe the accounting practices Islamic Bank over the countries (Ahmad et al., 1998). In the same way, these have not yet received the general recognition to be references that facilitate cross border information sharing and financial flows. Accordingly, diversity without a set of common references is likely to compound the challenges of cross border comparisons and may put Islamic banking services at a competitive disadvantage 
(Ahmad et al., 1998; Amihud, DeLong, \& Saunders, 2002; Ilias, 2010). In such situation to address the above issues, all the Islamic Banks over the world should maintain common accounting standards which are provided by Accounting and Auditing Organization for Islamic Financial Institutions (AAOIFI). The AAOIFI should also work to find out the way of solution for the conflict between the accounting standard conventional Bank and Islamic Bank based on the sharia principles. The specific objectives of AAOIFI are:

- To develop accounting and auditing thoughts relevant to Islamic financial institutions;

- To disseminate accounting and auditing thoughts relevant to Islamic financial institutions and its applications through training, seminars, publication of periodical newsletters, carrying out and commissioning of research and other means;

- To prepare, promulgate and interpret accounting and auditing standards for Islamic financial institutions; and

- To review and amend accounting and auditing standards for Islamic financial institutions.

\section{Development of Islamic Capital Market}

The Islamic capital market has some of regulatory and shariah compliant standard challenges for smoothly expanding Islamic Banking activities in the cross border boundary. Well formed Islamic capital markets will not only benefit borrowers and institutional investors as well as enhance the stability of Islamic banks, providing them with improved portfolio, liquidity, and risk management tools. But there are certain obstacles must be faced to establish good structure Islamic capital market, especially host country government have to take the responsibility to support in the legal and regulatory issues(Ahmad et al., 1998; Zamir Iqbal, 2007). Because of Ijarah or leasing is the one of most important mode of Islamic Banking activities. Normally the owner of operating assets enters into a leasing transaction. If the owner of operating assets is often the government itself or related public sector bodies, the relevant laws and regulations in the host country may not allow these bodies to pledge or lease assets needed to structure an ijarah transaction. This is a fundamental point; the host country's policy actions are a key prerequisite for further market development(Ahmad et al., 1998; Gavin, Gibson, McCrum, \& Summers, 2010; Zamir Iqbal, 2007).

\section{CONCLUSION}

As the aim of this paper is to identify the major regulatory challenges are faced by Islamic Bank in the issues of safety net to protect the risk of bearing loses of depositors over the world in the cross-border activities. The study has provided the regulatory boundary that should developed by Islamic Bank authorities over the world to face the existing challenges for the smooth future. Especially the study found that the Islamic banking are facing challenges to make appropriate rules and regulations for providing right safety against the deposit of customers with a conventional counter parts base on the Islamic sharia principles. Especially,in the area of "chartering or licensing function, chartering or licensing function, prudential regulation and supervision, deposits in the central bank, intervention and resolution mechanisms and capital adequacy standard" for safety net issues of Islamic banks. Moreover, it will also be useful to build bridges between existing Islamic banks and those conventional banks that are interested to do banking on Islamic Principles. Such strategic alliances will benefit both sides in the same 
field. Finally, the Islamic banks need to adopt an appropriate risk management system not only for their own portfolio, but also for that of their clients. Diversification and risk management are closely associated with the degree of market incompleteness. Thus, the study recommended that the policy maker has to pay attention to solve above regulatory issues to face the existing challenges for the smooth future.

\section{REFERENCES}

Abdul-Rahman, Y. (1999). Islamic instruments for managing liquidity. International Journal of Islamic Financial Services, 1(1), 1-7.

Ahmad, A., Khan, T., \& Iqbal, M. (1998). Challenges Facing Islamic Banking (Vol. Occational 01). Jeddah: Islamic Research and Training Isntitue, IDB.

Ainley, M., Mashayekhi, A., Hicks, R., Rahman, A., \& Ravalia, A. (2007). Islamic Finance in the UK: Regulation and Challenges. London: The Financial Service Authority.

Amihud, Y., DeLong, G. L., \& Saunders, A. (2002). The effects of cross-border bank mergers on bank risk and value. Journal of International Money and Finance, 21(6), 857-877.

Bashir, A. H. M. (1999). Risk and profitability measures in Islamic banks: the case of two Sudanese banks. Islamic Economic Studies, 6(2), 1-24.

Bashir, A. H. M. (2001). Assessing the performance of Islamic banks: some evidence from the Middle East.

El-Hawary, D., Grais, W., \& Iqbal, Z. (2004). Regulating Islamic financial institutions: The nature of the regulated. World.

Gavin, J., Gibson, N., McCrum, P., \& Summers, M. (2010). Annual review of Islamic Banking and Finance, The Gulf.

Grais, W. (2008). Islamic Banking: Policy and Institutional Challenges. Journal of Islamic Economics Banking and Finance, 4(1).

Hassan, M. K., \& Dicle, M. F. (2005). Basel II and Regulatory Framework for Islamic Banks. Journal of Islamic Economics, Banking and Finance, 1(1).

Hassan, M. K., \& Dicle, M. F. (2005). Basel II and regulatory framework for Islamic banks. Islamic Economics, Banking and Finance: Islami Bank Training and Research Academy (IBTRA), 1(1), 1-16.

Hegazy, I. A. (1995). An Empirical Comparative Study Between Islamic and Commercial Banks'selection Criteria In Egypt.International Journal of Commerce and Management, 5(3), 46-61.

I.F.S.B. (2005). Capital Adequacy Standard For Institutions (Other Than Insurance Institutions) Offering Only Islamic Financial Services Paper presented at the Capital Adequacy Working Group

Ilias, S. (2010). Islamic Finance: Overview and Policy Concerns: Congressional Research Service, 7-5700,www.crs.gov RS22931.

Iqbal, Z. (2007). Challenges Facing Islamic Financial Industry. Journal of Islamic Economics, Banking and Finance, 3(1), 149-162.

Iqbal, Z., \& Mirakhor, A. (1999). Progress and challenges of Islamic banking. Thunderbird International Business Review, 41(45), 381-405.

JR.Barth, Caprio, G. J., \& Levine, R. (2000). Banking systems around the globe: do regulation and ownership affect performance and stability? World Bank Working

Lewis, M., \& Algaoud, L. M. (2001). Islamic banking: Edward Elgar. 
Muljawan, D., Dar, H. A., \& Hall, M. J. B. (2004). A capital adequacy framework for Islamic banks: the need to reconcile depositors' risk aversion with managers' risk taking. Applied Financial Economics, 14(6), 429-441.

Naghipour, M., Rasht, I., \& Pourmohammad, M. (2012). The Significant Role of the Intellect in Confronting Contemporary Global Challenges: The Taught of the Holy Quran. Global Journal Al-Thaqafah, $2(2), 47$.

Sundararajan, V., \& Errico, L. (2002). Islamic financial institutions and products in the global financial system: Key issues in risk management and challenges ahead: International Monetary Fund.

Tahir, I. M., \& Bakar, N. M. A. (2009). Islamic Banking Operations: Preparing the Fit for Internationalization. Journal of Islamic Economics Banking and Finance, 5(3).

Van Greuning, H., Iqbal, Z., \& mondiale, B. (2008). Risk analysis for Islamic banks: World Bank.

Weigand, C., \& Grosh, M. (2008). Levels and patterns of safety net spending in developing and transition countries. World Bank Social Protection Discussion Paper, 817.

\section{Copyrights}

Copyright for this article is retained by the author(s), with first publication rights granted to the journal. This is an open-access article distributed under the terms and conditions of the Creative Commons Attribution license (http://creativecommons.org/licenses/by/4.0/) 